\title{
A Look at the Relationship Between the Spiro and Toltec Centers on the Arkansas River: A View from the Ancient Nile Valley
}

Frank Winchell

Unknown

Follow this and additional works at: https://scholarworks.sfasu.edu/ita

Part of the American Material Culture Commons, Archaeological Anthropology Commons, Environmental Studies Commons, Other American Studies Commons, Other Arts and Humanities Commons, Other History of Art, Architecture, and Archaeology Commons, and the United States History Commons

Tell us how this article helped you.

This Article is brought to you for free and open access by the Center for Regional Heritage Research at SFA ScholarWorks. It has been accepted for inclusion in Index of Texas Archaeology: Open Access Gray Literature from the Lone Star State by an authorized editor of SFA ScholarWorks. For more information, please contact cdsscholarworks@sfasu.edu. 


\section{A Look at the Relationship Between the Spiro and Toltec Centers on the Arkansas River: A View from the Ancient Nile Valley}

\section{Creative Commons License}

\section{(c) (1) (8)}

This work is licensed under a Creative Commons Attribution-NonCommercial 4.0 International License 


\title{
A LOOK AT THE RELATIONSHIP BETWEEN THE SPIRO AND TOLTEC CENTERS ON THE ARKANSAS RIVER: A VIEW FROM THE ANCIENT NILE VALLEY
}

\author{
by Frank Winchell
}

This paper will look into the relationship between the civic-ceremonial centers of Toltec and Spiro and the intervening area along the Arkansas Valley of Arkansas and eastern Oklahoma. Although it may first appear that there were two separate developments along the Arkansas Valley, this paper presents the possibility that the centers of Toltec and Spiro were intrinsically involved with one another, and that one may have risen to preeminence at the expense of the other. Indeed, the collapse of Toltec and the rise of Spiro may explain why the Arkansas Valley east of Spiro was not heavily occupied during the early part of the Mississippian period. The discussion of these two centers along the Arkansas Valley will also be put into the perspective of the ancient Nile Valley. Here, similar developments and events led to the demise of the Nubian A-Group culture and the virtual abandonment of their territory south to the First Cataract. Using the Nile Valley as an analytical model, it will be proposed that interactions along the Arkansas River played a very important role in the development at Spiro.

The centers of Toltec and Spiro share the distinction of being the two primary points of cultural development along the Arkansas Valley during the Late Woodland and Late Prehistoric periods, respectively. Toltec, through the Plum Bayou culture, emerged first along the middle portion of the Arkansas Valley, reaching a height of development sometime between A.D. 800 and 900 (Rolingson 1982:1-6; 1990:44-46). At this time, the Toltec center commanded a strategic point along the Arkansas River where it opened into the broad, Lower Mississippi Valley. Up the narrower passage between the Ozarks and Ouachita highlands, approximately $200 \mathrm{~km}$ from Toltec, Spiro began as a significant local center on the river as early as A.D. 700, but did not reach regional prominence until sometime after A.D. 900 (Bell 1984:228; Brown 1984a:11-20, 1984b:259-262; Brown et al. 1978). Of course, during the first half of the Mississippian period, Spiro stood supreme over the prime bottomland stretch of the Arkansas River at the doorstep of the Great Plains.

It has been known for some time that during Spiro's formative development, associated with the Evans phase (Orr 1946; 1952:246-247), the center may have been related to, or was at least influenced by, the Plum Bayou culture centering at Toltec (Brown 1984a:12-15; Rolingson 1982; 1990:46; Sabo et al. 1990:78; Schambach 1992:13-16). The relationship between the Evans phase and the Plum Bayou culture is not well understood. However, both developments were involved with the construction of platform and dome-shaped mounds, with burial of the dead in accretional units, and with a common set of ceramics which were similar in decoration, vessel shape, and paste composition (Brown 1984a; Hemmings and House 1985; Rolingson 1982).

The essential difference between the Plum Bayou culture and the Evans phase was the greater scale and magnitude of the mound and earthwork construction at the principal Plum Bayou center of Toltec. Between A.D. 700 and 900, eighteen mounds were constructed at Toltec; all were enclosed within a 40 ha area which was surrounded by a 1600 meter long earthen embankment (Rolingson 1982:1, 1990:38). The majority of the mounds at Toltec were either platform or flat-topped, and pyramidal-shaped.

As a group they were similar to other contemporary Coles Creek mound centers located farther downstream within the Lower Mississippi Valley. Nevertheless, the massive mound complex at Toltec was unique and significantly larger than most Lower Mississippi Valley mound centers at the time; the latter usually consisted of three prominent mounds surrounding a triangularshaped plaza (Phillips 1970:555, Rolingson 1982:63; Williams 1956:58-60).

During the Late Woodland period, Toltec was clearly the primary center within the Arkansas Valley, extending its influence down river into the 
Mississippi Valley and overland into the Great Bend area of the Red River (Rolingson 1982, 1990; Schambach 1982:182-183). Toltec also pushed its influence farther up river along the Arkansas Valley into the southern Ozark region where the construction of platform and domeshaped mounds coincided with the beginning of the Evans phase (Brown 1984a:11-15). During this time, Spiro emerged as one of eight or so smaller mound centers within the southern Ozark region of eastern Oklahoma. Curiously, farther down river from Spiro along the Arkansas Valley, there were no other mound centers of this period until the Plum Bayou occupation at Point Remove, located approximately $100 \mathrm{~km}$ upstream from Toltec (Rolingson 1990:39). The paucity of sites dating to this period along this stretch of the valley may be due to the fact that very little archaeological work has been conducted there. Nevertheless, despite the data gaps, there can be little question that there were significant influences moving up river from the Plum Bayou center at Toltec through the Arkansas Valley and into the Spiro area (Brown 1984a:12; Sabo et al. 1990: 82). It is also likely that the settlement at Spiro during this time was tributary to the larger center, down river at Toltec.

It is only after the demise of Toltec that the center of Spiro began to assert its influence as a dominant center within the Arkansas Valley. At the beginning of the Harlan phase in the tenth century A.D., other southern Ozark centers such as the Harlan site were nearly or equally as important. Nonetheless, Spiro's strategic location on the Arkansas River would have allowed it to take supreme advantage of the political and cultural vacuum left by the disappearance of the Plum Bayou culture at Toltec. By the beginning of the Spiro phase in the mid-thirteenth century A.D., the center had grown considerably, containing at least 12 mounds within a 30 ha area. Of course, at this time Spiro had eclipsed all other rival centers within the Arkansas Basin.

As with the Evans phase, it appears that both Harlan and Spiro phase occupations extended only a little farther down river from the Spiro locality (Hoffman 1977; Sabo et al. 1990:111). However, in contrast to Late Woodland times, the Arkansas Valley east of Spiro, all the way down to Toltec, appeared to have been a virtual backwater during the first part of the Mississippian period. Thus, it would appear natural for the Spiro center to have extended its influence down the Arkansas River where the "drainage patterns [would have favored] cultural interactions to the east and west" (Brown et al. 1978:170). Nevertheless, the occupants at Spiro chose to make more meaningful contacts directly to the south with the Red River Caddoan cultures, and to the northeast with cultures in the Middle Mississippi Valley (Brown et al. 1978:170; Sabo et al. 1990:111113; Schambach 1992). In assessing the location of all known Mississippian period occupations along the Arkansas River and its major tributaries within the southern Ozarks, it is apparent that the vast majority of them were situated up river from Spiro (Sabo et al. 1990:83, Fig. 30). Of the 40 recorded Mississippian period sites in the region, 32 are situated up river from the center whereas only eight are within the Arkansas basin down river. Indeed, many of these occupations down river from Spiro fall within the latter part of the Mississippian period after the center was abandoned. As mentioned above, this imbalance may be due to a lack of archaeological investigations carried out along the Arkansas Valley east of the Oklahoma state line. On the other hand, it is possible that this portion of the Arkansas Valley was significantly depopulated when Spiro assumed its prominent position on the river after the demise of Toltec. Perhaps the ephemeral Mississippian occupations noted at Toltec and $90 \mathrm{~km}$ upstream at the neighboring Alexander site are another indication of this population decline within the central Arkansas Valley after the disappearance of the Plum Bayou culture (StewartAbernathy 1982:53; House 1985:101).

Shifting back four thousand years across the globe to the ancient Near East, it is interesting to compare the possible depopulation of the Middle Arkansas Valley at the time of Spiro's florescence with what happened in the Nubian Nile Valley when the first Egyptian dynasty appeared at Hierakonpolis at the end of the fourth millennium B.C. Between the fifth and fourth millennium B.C., the Nile Valley south of present-day Cairo and north of the Second Cataract was occupied by Egyptian and Nubian Predynastic cultures. At the beginning of the fifth millennium B.C., the cultural boundary between the two Nilotic societies was not well defined. However, by 3500 B.C. the unnavigable stretch of river through the First Cataract had become the established political boundary. Like the Evans phase and the Plum Bayou culture along the Arkansas Valley, the Nilotic Egyptian and Nubian Predynastic societies shared a remarkably similar cultural repertoire. Although this was most notably seen with the ceramics, it was recognized in other traits, such 
as burial practices, settlement patterns, and subsistence strategies (Nordstrom 1972:28; Reisner 1910:314; Winchell 1992:403-412). After comparing the earliest settlements north and south of the First Cataract, it is still unclear whether the Predynastic Egyptians spawned a cultural florescence among the Nubians or vice versa. In either case, it is evident that the Predynastic Egyptians and Nubians actively traded with one another north and south of the First Cataract. This reciprocal relationship between the two cultures stopped abruptly after 3100 B.C. when the Egyptian polities north of the First Cataract united under the single rulership of the first Dynastic king (Emery 1961). At the onset of the First Dynasty, Nubian A-Group occupations essentially disappeared south of the First Cataract, signifying a drastic cultural collapse had taken place. Based on archaeological evidence and early Old Kingdom texts, it is quite evident that the collapse of the Predynastic Nubian A-Group culture was the result of a direct political response inflicted by the Egyptians of the First Dynasty. They essentially stopped all trading activities with the Nubians, and may have even resorted to some raiding south of the First Cataract (Nordstrom 1972:29-32). As it is important to note, however, these Egyptians did not colonize the former territory of the Nubian A-Group, and the Nile Valley south of the First Cataract was pretty much left vacant until the beginning of the Middle Kingdom period.

In using this scenario from the Nile Valley, it is interesting to speculate that the area along the Arkansas Valley between Toltec and Spiro may have suffered from the similar effects of a political realignment. Thus, the collapse of Toltec and the disappearance of the Plum Bayou culture may have been caused by the rise of Spiro. However, unlike circumstances which seem so clear between Predynastic Nubia and the sudden rise of the first Kingship in Egypt, the connections between the fall of Toltec and rise of Spiro are not as self-evident. For example, it appears that the Plum Bayou occupation at Toltec ended shortly after A.D. 900. Spiro, on the other hand, does not appear to have taken off in a big way until more than three hundred years later during the Spiro phase. Indeed, the activities associated with the Great Mortuary appear to have taken place around A.D. 1388 (Brown 1984a:16).

What we are left with at Spiro is the shadowy Evans phase and the slightly better known Harlan phase, bridging the critical gap between the dis- appearance of Toltec and the sudden rise of the Spiro site. But what about the Evans and Harlan phases? As discussed above, it is becoming more evident that the connections between the Evans phase and the Plum Bayou culture were quite significant, indicating that there was a meaningful interaction taking place along the Arkansas Valley from Toltec to Spiro (Brown 1984a). The seemingly anomalous presence of Late Woodland shell tempered ceramics at Toltec and the Alexander site may also give some indication that at least some goods were being sent down river from the Spiro area (Hemmings 1985:38-41; StewartAbernathy 1982:50-53).

It also appears that the Harlan phase developed in situ out of the Evans phase as indicated by the excavations at the Harlan site (Bell 1972; Brown 1984a:15). It is likely, however, that the same type of transition also took place at Spiro even though the evidence may not be as clear. In either case, Spiro was probably the major center by the beginning of the Harlan phase (Bell 1984:228; Rogers 1989:167), if not earlier. It is estimated that Spiro had at least eleven mounds constructed during this period while Harlan had only four (Rogers 1989:165). In contrast, all other Harlan phase mound centers in the region had either one or two mounds.

The importance of the Harlan phase in the Spiro area is that it represented a significant shift towards trading, which may have been "a major economic activity" at the time (Bell 1984: 228). The transition to the Harlan phase from the Evans phase also seems to have been quite dramatic, suggesting that change within the Arkansas Valley near Spiro was anything but gradual.

The point to be made is that the period from the demise of Toltec to the rise of Spiro as the paramount center in the Arkansas Valley was quite short, if not instantaneous. The question then arises as to whether it was purely a coincidence that Spiro rose to its preeminent position at the same time that Toltec came to a halt. Granted, there is a distance of more than $200 \mathrm{~km}$ between Toltec and Spiro. Nevertheless, referring back to the Nile Valley, Hierakonpolis, which was the place of origin of the Egyptian First Dynasty, was more than $500 \mathrm{~km}$ from the nearest Nubian A-Group settlements.

If some sort of political shift took place along the Arkansas Valley from Toltec to Spiro, how could it be detected in the archaeological record? 
It seems apparent that a critical testing ground for this hypothesis lies in the relatively unknown area along the Arkansas Valley between Toltec and Spiro. By using the Nubian Nile Valley abandonment analogue as a model, one could predict that Late Woodland occupations would exist along the Arkansas Valley down river from the Spiro area, whereas early Mississippian occupations dating after A.D. 900 would not be found there. This kind of simple dichotomy would be based on the assumption that for the transference of ideas to have taken place between Spiro and Toltec there must have been Late Woodland occupations between the two centers. However, after A.D. 900 , when the proposed shift in regional influence changed from Toltec to Spiro, the old lines of communication would have been cut off and occupations along the Arkansas Valley east of Spiro would have been significantly curtailed. Putting climatological factors aside, if there are very few signs of early Mississippian occupation in this part of the valley, this would indicate that some sort of severe political repercussion may have taken place. Of course, all this would have occurred at the beginning of the Harlan phase when Spiro became a powerful center.

To contradict this model, one would want to demonstrate that a continuous sequence of occupations did occur along the Arkansas Valley east of Spiro from the end of the Late Woodland period into the early Mississippian period. At this time, a continuous sequence from A.D. 900 to 1000 in the Toltec area of the Arkansas Valley cannot be confirmed.

A critical question arises about how far upriver within the Arkansas Valley the Plum Bayou culture existed. Likewise, how far downriver from Spiro did the Evans phase exist? As mentioned above, it appears that Harlan and Spiro phase occupations never did go much farther down river from the Spiro center. Based on this information, it is possible that a cultural boundary did exist just east of Spiro, especially where the Arkansas Valley begins to narrow when it passes between the Ozark and Ouachita highlands. Of course, the question arises as to who was situated down river from Spiro, and could they possibly have been people associated with the Plum Bayou culture?

Both the cultural and bioarchaeological data derived from the Middle and Late Woodland occupations at the Alexander site suggests that the resident population living there was much more similar to Fourche Maline groups farther up the Arkansas Basin than to other groups farther down river in the Lower Mississippi Valley (Hemmings and House 1985).

In short, the Arkansas Valley between the centers of Spiro and Toltec promises to be a fertile proving ground in developing models on the origins of the former site. In invoking the old Childean term of "stimulus diffusion" (not to mention the old Boasian model of historical particularism), the flow of ideas stemming up the Arkansas River from Toltec may have had a profound effect on the formative development at Spiro during the Evans phase. During the Harlan phase, Spiro's rapid ascent to its paramount position on the Arkansas River may have been a direct effect of a cultural collapse at Toltec. And from the distant view of the ancient Nile Valley, the early Mississippian period center at Spiro may have been an active participant in that collapse.

\section{Acknowledgements}

Thanks to Duane Peter for his financial support of this project. This paper was presented at the 35th Caddo Conference in Norman, Oklahoma on March, 1993.

\section{REFERENCES CITED}

Bell, R. E.

1972 The Harlan Site, Ck-6, A Prehistoric Mound Center In Cherokee County, Eastern Oklahoma. Oklahoma Anthropological Society Memoir 2. Oklahoma City.
Bell, R. E. (editor)

1984 Prehistory of Oklahoma. Academic Press, New York. 
Brown, J. A.

1984a Prehistoric Southern Ozark Marginality: A Myth Exposed. Missouri Archeological Society Special Publications 6. Columbia, Missouri.

1984b Arkansas Valley Caddoan: The Spiro Phase. In Prehistory of Oklahoma, edited by R. E. Bell. Pp. 241-263. Academic Press, New York.

Brown, J. A., R. E. Bell, and D. G. Wyckoff

1978 Caddoan Settlement Patterns in the Arkansas River Drainage. In Mississippian Settlement Patterns, edited by B. D. Smith. Pp. 169-200. Academic Press, New York.

Emery, W. B.

1961 Archaic Egypt: Cultures and Civilization in Egypt Five Thousand Years Ago. Cox and Wyman Ltd., Reading.

Hemmings, E. T.

1985 Analysis of Materials. In The Alexander Site, edited by E. T. Hemmings and J. H. House. Arkansas Archeological Survey Research Series 24:27-48. Fayetteville.

Hemmings, E. T. and J. H. House (editors)

1985 The Alexander Site. Arkansas Archeological Survey Research Series 24. Fayetteville.

Hoffman, M. P.

1977 An Archeological Survey of the Ozark Reservoir in West-Central Arkansas. In Ozark Reservoir Papers: Archeology in West-Central Arkansas 1965-1970, by M. P. Hoffiman, N. E. Myer, D. Printup, and C. L. Bond. Arkansas Archeological Survey Research Series 10:1-44. Fayetteville.

House, J. H.

1985 Summary and Conclusions. In The Alexander Site, edited by E. T. Hemmings and J. H. House. Arkansas Archeological Survey Research Series 24:99-110. Fayetteville.

Nordstrom, H.

1972 Neolithic and A-Group Sites. Scandinavian University Books, Copenhagen.
Orr, K. G.

1946 The Archaeological Situation at Spiro, Oklahoma: A Preliminary Report. American Antiquity 11(4):228-256.

1952 Survey of Caddoan Area Archaeology. In Archaeology of Eastern United States, edited by J. B. Griffin. Pp. 239255. University of Chicago Press, Chicago.

Phillips, P.

1970 Archaeological survey in the Lower Yazoo Basin, Mississippi, 1949-1955. Papers of the Peabody Museum of Archaeology and Ethnology 60.

Reisner, G. A.

1910 The Archaeological Survey of Nubia, Report for 1907-1908. 2 Vols. National Printing Department, Cairo.

Rogers, J. D.

1989 Settlement Contexts For Shifting Authority In The Arkansas Basin. In Contributions To Spiro Archeology: Mound Excavations and Regional Perspectives, edited by J. D. Rogers, D. G. Wyckoff, and D. A. Peterson. Oklahoma Archeological Survey, Studies in Oklahoma's Past 16:159-176. Norman.

Rolingson, M. A. (editor)

1982 Emerging Patterns of Plum Bayou Culture. Arkansas Archeological Survey Research Series 18. Fayetteville.

1990 The Toltec Mounds Site: A Ceremonial Center in the Arkansas River Lowland. In The Mississippian Emergence, edited by B. D. Smith. Pp. 27-44. Smithsonian Institution Press, Washington, D.C.

Sabo, G. III, A. M. Early, J. C. Rose, B. A. Burnett, L. Vogele, and J. P. Harcourt

1990 Human Adaptation in the Ozark and Ouachita Mountains. Arkansas Archeological Survey Research Series 31. Fayetteville.

Schambach, F. F.

1982 An Outline of Fourche Maline Culture in Southwest Arkansas. In Arkansas Archeology in Review, edited by $\mathrm{N}$. Trubowitz and M. D. Jeter. Arkansas 
Archeological Survey Research Series 15:132-197. Fayetteville.

1992 Some New Interpretations of Spiroan Culture History. Unpublished manuscript.

Stewart-Abernathy, J. C.

1982 Ceramic studies at the Toltec Mounds site: basis for a tentative cultural sequence. In Emerging Patterns of Plum Bayou Culture, edited by M. A. Rolingson. Arkansas Archeological Survey Research Series 18:44-53. Fayetteville.
Williams, S.

1956 Settlement patterns in the Lower Mississippi Valley. In Prehistoric Settlement Patterns in the New World, edited by G. R. Willey. Wenner-Gren Publications in Anthropology 23:52-62.

Winchell, $\mathrm{F}$.

1992 The Butana Group Ceramics and Their Place in the Neolithic and Post-Neolithic Eras of Northeast Africa. Ph.D. dissertation (Southern Methodist University). University Microfilms International, Ann Arbor, Michigan.

\section{TH CADDO CONFERENCE (1993) ABSTRACTS}

BROWN, James (Northwestern University). THE POTENTIAL FOR CHRONOLOGICAL REFINEMENT IN CADDOAN ARCHAEOL$O G Y$.

Far greater effort needs to be exerted in developing the kind of precision in regional chronologies of material culture that will help address contemporary issues on ethnicity, as well as more sophisticated questions respecting traditional topics of study. The number of time sensitive attributes of Caddoan ceramics and other items already documented indicate rich possibilities. This paper draws attention to issues that chronological distinctions of greater precision have a major contribution to make.

BURNS, Stephanie (University of Oklahoma). PALEODEMOGRAPHY OF THE MACKEY SITE (34LF29).

This paper will present preliminary bioarchaeological information acquired from the burial population at the Mackey site (34LF29). The site is a black midden mound located near the Fourche Maline Creek in the Wister Valley of southeastern Oklahoma. Excavation of the site was undertaken in 1940 by the WPA under the supervision of Phil Newkumet. Recent curation and analysis of the skeletal remains has yielded demographic information on the 160 burials recovered. These data will be presented and compared to similar demographic information from the Sam, Wann, McCutchan-McLaughlin, and Bug Hill sites.
DICKSON, Don R. (Historic Preservation Associates). SOME PROBLEMS ENCOUNTERED IN IDENTIFYING LITHIC RAW MATERIALS FROM ARCHEOLOGICAL SITES.

Recently, many archeologists have attempted to relate each chert tool or item of debitage recovered in excavation to the most specific geological stratum or member producing that type of chert. Unfortunately, few archeologists understand geology well enough to recognize parent carbonates in the field, and far too many use out-of-date publications and generalized geological maps to put together comparative collections of raw material. This paper attempts to point out some of the problems encountered today in identifying lithic categories recovered during excavation, and to suggest methods of minimizing the impact of these problems.

FIELDS, Ross C. (Prewitt and Associates, Inc.). RECENT EXCAVATIONS AT ARCHAIC, WOODLAND, AND CADDOAN SITES AT COOPER LAKE, DELTA AND HOPKINS COUNTIES, TEXAS.

Since 1990, mitigative excavations have been completed at six prehistoric sites at Cooper Lake in Delta and Hopkins counties, Texas. Finley Fan (41HP159) is a stratified middle and late Archaic site; John's Creek (41DT62) dates mostly to the Woodland period; Tick (41DT6) and Spike (41DT16) are multicomponent Woodland and early Caddoan middens; Spider Knoll (41DT11) is an early Caddoan farmstead; and Peerless Bot- 